\title{
PENERAPAN MODEL PROBLEM BASED LEARNING UNTUK MENINGKATKAN HASIL BELAJAR MATEMATIKA SISWA SMP
}

\author{
Sandi Lukito ${ }^{1}$, Hanifah Hanifah ${ }^{2}$, Syafdi Maizora ${ }^{3}$ \\ Universitas Bengkulu, FKIP, Program Studi Pendidikan Matematika \\ email: ${ }^{1}$ sandilukitouwais@ gmail.com, ${ }^{2}$ hanifah@unib.ac.id, ${ }^{3}$ syafdiichiemaizora@unib.ac.id
}

\begin{abstract}
ABSTRAK
Penelitian ini bertujuan untuk meningkatkan hasil belajar siswa dengan menerapkan model Problem Based Learning. Penelitian ini adalah penelitian Tindakan Kelas (PTK) dengan teknik pengumpulan data melalui tes hasil belajar siswa. Subjek penelitian ini adalah siswa kelas VII 6 SMP Negeri 1 Kota Bengkulu Semester Genap Tahun Ajaran 2017/2018 berjumlah 33 siswa. Hasil penelitian menunjukkan bahwa penerapan model Problem Based Learning dapat meningkatkan hasil belajar matematika siswa. Berdasarkan Kurikulum 2013 di SMP Negeri 1 Kota Bengkulu menyatakan ketuntasan belajar untuk (a) individu : jika siswa mendapat nilai $\geq$ 80, (b) klasikal: jika $80 \%$ siswa mendapat nilai $\geq 80$. Peningkatan hasil belajar matematika siswa dapat dilihat dari nilai rata-rata hasil belajar siswa siklus I, siklus II dan siklus III secara berturut-turut adalah 74,27; 80,42; dan 82,96 serta ketuntasan belajar klasikal siklus I, siklus II dan siklus III secara berturut-turut adalah $72,73 \%$; 78,79\%; dan 84,85\%.
\end{abstract}

Kata kunci: Hasil Belajar, Problem Based Learning.

\section{ABSTRACT}

The research aimed to improve the activity and learning outcomes of learners with Problem Based Learning model. This research was a Classroom Action Research. To collect the data, the researcher used test learning result techniques. The subject of this research was student of class VII 6 at SMP Negeri 1 Kota Bengkulu in academic yeard 2017/2018 with total number of 33 students. The result of this research shows that applying Problem Based Learning model can improve the result of students mathematic learning. Based on 2013 curriculum in SMP N 1 Kota Bengkulu represents learning for (a) individual : if students get value $\geq 80$, (b) classical : if $80 \%$ of students get grades $\geq 80$. The improvement of students learning result can be seen from the average score in cycle I, cycle II, and cycle III in a row are 74,27; 80,42; and 82,96. Futhermore, the completeness of classical learning in cycle I, cycle II, and cycle III in a row are $72,73 \%$; 78,79\%; dan 84,85\%.

Key words : Learning Outcomes, Problem Based Learning.

\section{PENDAHULUAN}

Matematika merupakan mata pelajaran yang sangat dibutuhkan dalam kehidupan sehari-hari. Banyak permasalahan yang dapat diselesaikan dengan teori-teori matematika. Matematika sebagai salah satu ilmu dasar memiliki peranan penting dalam mencerdaskan siswa karena dapat menumbuhkan kemampuan penalaran yang sangat dibutuhkan dalam perkembangan ilmu dan teknologi. Mata pelajaran matematika juga dapat membekali peserta didik dengan kemampuan berpikir logis, analitis, sistematis, kritis, dan kreatif, serta kemampuan bekerjasama (Depdiknas, 2006:387). 
Pembelajaran matematika di sekolah bertujuan untuk mempersiapkan siswa agar sanggup menghadapi perubahan keadaan di dalam kehidupan dan di dunia yang selalu berkembang melalui latihan bertindak atas dasar pemikiran secara logis, rasional, kritis, cermat, jujur, efisien dan efektif. Siswa diharapkan dapat mengaplikasikan ilmu matematika dalam kehidupan sehari-hari dan dalam mempelajari berbagai ilmu pengetahuan (Susanto, 2014:189).

Berdasarkan hasil observasi dan wawancara dengan guru mata pelajaran matematika Ibu Oktarina Christianty, M.Pd.Mat di kelas VII 6 SMP Negeri 1 Kota Bengkulu, diperoleh informasi bahwa hasil belajar siswa pada mata pelajaran matematika berada dibawah rata-rata Kriteria Ketuntasan Minimum (KKM) yaitu 80. Siswa yang tuntas pada mata pelajaran matematika hanya $75 \%$ dari 32 siswa.

Metode pembelajaran yang dilaksanakan di dalam kelas VII 6 SMP Negeri 1 Kota Bengkulu menggunakan metode diskusi, akan tetapi guru masih kurang optimal dalam menggunakan model pembelajaran. LKS dan kerja kelompok di dalam kelas kurang dirancang sehingga pelaksanaannya kurang efektif. Pada saat pembelajaran terlihat bahwa peserta didik masih sulit untuk dikondisikan. Hal ini terlihat dari terdapat peserta didik yang berbicara dengan temannya saat diskusi kelompok. Hanya siswa tertentu saja yang aktif dalam mengerjakan tugas kelompok, serta terlihat minimnya interaksi antara guru dengan peserta didik pada saat kegiatan pembelajaran berlangsung. Adapun faktor lain yang menyebabkan rendahnya hasil belajar yaitu, siswa yang baru masuk (kelas VII) bukan lagi siswa pilihan, akan tetapi berdasarkan kebijakan pemerintah menggunakan mekanisme zonasi, sekolah wajib menyerap 90\% dari total daya tampung peserta didik baru yang bertempat tinggal di dekat sekolah (Permendikbud Nomor 17 tahun 2017 tentang PPDB pasal 15).
Salah satu model pembelajaran yang direkomendasikan dalam kurikulum 2013 adalah model Problem Based Learning (Permendikbud No.103 Tahun 2014). Model Problem Based Learning akan melatih siswa menghadapi berbagai masalah baik itu masalah perorangan maupun masalah kelompok untuk dipecahkan sendiri atau secara bersama-sama. Model Problem Based Learning melatih siswa untuk mendesain suatu penemuan, berfikir dan bertindak kreatif, memecahkan masalah yang dihadapi secara realistis, mengidentifikasi dan melakukan penyelidikan, menafsirkan dan mengevaluasi hasil pengamatan, merangsang kemajuan berpikir siswa untuk menyelesaikan masalah yang dihadapi dengan tepat, serta dapat membuat pendidikan sekolah lebih relevan dengan kehidupan khususnya di dunia kerja.

Model Problem Based Learning bercirikan penggunaan masalah kehidupan nyata sebagai sesuatu yang harus dipelajari oleh siswa untuk melatih dan meningkatkan keterampilan berpikir kritis sekaligus pemecahan masalah, serta mendapatkan pengetahuan konsep-konsep penting. Oleh karena itu guru harus memfokuskan diri untuk membantu siswa mencapai keterampilan mengarahkan diri. Dengan pengertian tersebut, maka model pembelajaran Problem Based Learning ini bisa digolongkan kedalam pembelajaran berbasis sains (Sitiatava, 2012 : 67).

Berdasarkan permasalahan yang ditemukan, telah dilakukan penelitian yang berjudul "Penerapan Model Problem Based Learning untuk Meningkatkan Hasil Belajar Matematika Siswa Kelas VII 6 SMP Negeri 1 Kota Bengkulu". Adapun tujuan dari penelitian tindakan kelas ini adalah untuk mengetahui cara meningkatkan hasil belajar siswa dalam penerapan model Problem Based Learning di kelas VII 6 SMP N 1 Kota Bengkulu. 


\section{Problem Based Learning}

Problem Based Learning merupakan salah satu model pembelajaran inovatif yang dapat memberikan kondisi belajar aktif kepada siswa. Ngalimun (2013 : 89) menyimpulkan Problem Based Learning adalah suatu model pembelajaran yang melibatkan siswa untuk memecahkan suatu masalah melalui tahaptahap metode ilmiah sehingga siswa dapat mempelajari pengetahuan yang berhubungan dengan masalah tersebut dan sekaligus memiliki keterampilan untuk memecahkan masalah. Rusman (2010 : 237) dalam Problem Based Learning, sebuah masalah yang dikemukakan kepada siswa harus dapat membangkitkan pemahaman siswa terhadap masalah, sebuah kesadaran akan kesenjangan, pengetahuan, keinginan memecahkan masalah, dan persepsi bahwa meraka mampu memecahkan masalah tersebut. Masalah yang disajikan dalam Problem Based Learning sebaiknya merupakan masalah autentik. Masalah autentik adalah masalah yang terdapat dalam kehidupan sehari-hari dan bermanfaat langsung jika ditemukan penyelesainnya. Langkah-langkah dalam pengajaran Problem Based Learning terjadi dalam 5 fase, berikut ini adalah tahap pembelajaran menurut Ibrahim dan Nur (Rusman 2012 : 243) :

Tabel 1 Sintaks Problem Based Learning

\begin{tabular}{|c|c|}
\hline Fase & Aktivitas Guru \\
\hline $\begin{array}{l}\text { Fase } 1 \text { : } \\
\text { Mengorientasikan } \\
\text { siswa pada masalah }\end{array}$ & $\begin{array}{l}\text { Menjelaskan tujuan } \\
\text { pembelajaran, logistik } \\
\text { (alat dan bahan) yang } \\
\text { diperlukan, memotivasi } \\
\text { siswa terlibat aktif pada } \\
\text { aktivitas pemecahan } \\
\text { masalah yang dipilih. }\end{array}$ \\
\hline $\begin{array}{l}\text { Fase 2: } \\
\text { Mengorganisasikan } \\
\text { siswa untuk belajar }\end{array}$ & $\begin{array}{lr}\text { Membantu } & \text { siswa } \\
\text { membatasi } & \text { dan } \\
\text { mengorganisasi } & \text { tugas } \\
\text { belajar } & \text { yang } \\
\text { berhubungan dengan } & \text { dengalah } \\
\end{array}$ \\
\hline Fase $3:$ & Mendorong \\
\hline
\end{tabular}

\begin{tabular}{|c|c|}
\hline $\begin{array}{l}\text { Membimbing } \\
\text { penyelidikan } \\
\text { individu maupun } \\
\text { kelompok }\end{array}$ & $\begin{array}{l}\text { mengumpulkan } \\
\text { informasi yang sesuai, } \\
\text { melaksanakan } \\
\text { eksperimen, } \\
\text { mencari dan } \\
\text { penjelasan } \\
\text { pemecahan. }\end{array}$ \\
\hline $\begin{array}{l}\text { Fase 4: } \\
\text { Mengembangkan } \\
\text { dan menyajikan } \\
\text { hasil karya }\end{array}$ & $\begin{array}{lr}\text { Membantu } & \text { siswa } \\
\text { merencanakan } & \text { dan } \\
\text { menyiapkan } & \text { karya } \\
\text { yang sesuai seperti } \\
\text { laporan, dan membantu } \\
\text { mereka untuk berbagi } \\
\text { tugas dengan temannya } \\
\text { masalah. }\end{array}$ \\
\hline $\begin{array}{l}\text { Fase 5: } \\
\text { Menganalisis dan } \\
\text { mengevaluasi } \\
\text { proses pemecahan } \\
\text { masalah }\end{array}$ & $\begin{array}{l}\text { Membantu siswa } \\
\text { melakukan refleksi } \\
\text { terhadap penyelidikan } \\
\text { dan proses-proses yang } \\
\text { digunakan selama } \\
\text { berlangsungnya } \\
\text { pemecahan. }\end{array}$ \\
\hline
\end{tabular}

Pembelajaran melalui model Problem Based Learning merupakan suatu rangkaian pendekatan kegiatan belajar yang diharapkan dapat memberdayakan siswa untuk menjadi seorang individu yang mandiri dan mampu menghadapi setiap permasalahan dalam hidupnya di kemudian hari. Dalam pelaksanaan pembelajaran, siswa dituntut terlibat aktif dalam mengikuti proses pembelajaran melalui diskusi kelompok. Sebagai suatu model pembelajaran, Problem Based Learning memiliki beberapa kelebihan, diantaranya yaitu (Sitiatava, 2012 : 82-83) : (1) Siswa lebih memahami konsep yang diajarkan karena siswa tersebut yang menemukan konsep; (2) Melibatkan siswa secara aktif dalam memecahkan masalah dan menuntut keterampilan berpikir siswa yang lebih tinggi; (3) Pengetahuan tertanam berdasarkan schemata yang dimiliki oleh siswa, sehingga pembelajaran lebih bermakna; (4) Siswa dapat merasakan manfaat pembelajaran, karena masalah-masalah yang diselesaikan langsung dikaitkan dengan kehidupan nyata; 
Menjadikan siswa lebih mandiri dan dewasa, mampu memberi aspirasi dan menerima pendapat orang lain, serta menanamkan sikap yang positif dengan siswa lainnya; (6) Pengondisian siswa dalam belajar kelompok yang saling berinteraksi terhadap pembelajaran dan temannya, sehingga pencapaian ketuntasan belajar siswa dapat diharapkan; (7) Problem Based Learning diyakini pula dapat menumbuhkan dan mengembangkan kemampuan kreativitas siswa, baik secara individual maupun kelompok, karena hampir setiap langkah menuntut adanya keaktifan siswa.

\section{Hasil Belajar}

Keberhasilan dari pembelajaran diukur dari seberapa jauh hasil belajar yang dicapai oleh siswa. Tercapai atau tidaknya tujuan pembelajaran dapat dilihat dari hasil belajar yang diperoleh siswa setelah proses pembelajaran selesai. Dimyati dan Mudjiono (2006: 250), hasil belajar merupakan hasil proses belajar dan ditunjukkan dengan penilaian dari guru sedangkan menurut Sudjana (2009: 22) hasil belajar adalah kemampuan-kemampuan yang dimiliki siswa setelah ia menerima pengalaman belajarnya.

Benjamin S. Bloom dalam Abdurahman (2009: 38), ada tiga ranah hasil belajar, yaitu ranah kognitif, afektif, dan psikomotorik. Penjabarannya adalah sebagai berikut : (1) Ranah kognitif terdiri dari enam jenis perilaku, yaitu pengetahuan, pemahaman, penerapan, analisis, sintesis, dan evaluasi, (2) Ranah afektif terdiri dari lima jenis perilaku, yaitu penerimaan, partisipasi, penilaian, penentuan dan sikap, (3) Ranah psikomotorik terdiri dari tujuh perilaku, yaitu persepsi, kesiapan, gerakan terbimbing, gerakan yang terbiasa, gerakan kompleks, penyesuaian pola gerakan, dan kreativitas.

Dari uraian di atas dapat disimpulkan bahwa hasil belajar adalah kemampuan yang dimiliki oleh siswa setelah mengalami proses belajar yaitu berupa kemampuan kognitif, afektif, dan psikomotorik.

\section{METODE PENELITIAN}

Jenis penelitian yang dilakukan adalah Penelitian Tindakan Kelas (PTK). PTK adalah proses pengkajian masalah pembelajaran didalam kelas melalui refleksi diri dan upaya untuk memecahkannya dengan cara melakukan berbagai tindakan yang terencana dalam situasi nyata serta menganalisis setiap pengaruh dari tindakan tersebut (Sanjaya, 2011 : 26). Menurut Arikunto (2006:16) ada beberapa ahli yang mengemukakan model penelitian tindakan dengan bagan yang berbeda, namun secara garis besar terdapat empat tahapan yang lazim dilalui, yaitu (1) perencanaan tindakan (planning), (2) pelaksanaan tindakan (acting), (3) pengamatan (observing), (4) refleksi (reflecting).

Penelitian ini dilakukan di SMPN 1 Kota Bengkulu. Populasi dalam penelitian ini adalah seluruh siswa kelas VII SMPN 1 Kota Bengkulu tahun ajaran 2017/2018. Subjek penelitian ini adalah siswa kelas VII 6 SMP Negeri 1 Kota Bengkulu yang berjumlah 33 siswa, dengan 1 orang siswa laki- laki dan 19 orang siswa perempuan.

Penilaian hasil belajar siswa untuk tiap siklus yaitu berupa nilai tes. Tes yang dilakukan akan digunakan untuk menganalisis tingkat keberhasilan tindakan. Hasil belajar siswa dikatakan berhasil jika telah memenuhi Kriteria Ketuntasan Minimal (KKM) yaitu $80 \%$ yaitu siswa memperoleh nilai $\geq 80$. Secara sederhana rumus nya adalah:

$$
\bar{X}=\frac{\sum X}{N}
$$

(Arikunto, 2006: 264)

Keterangan :

$\bar{X} \quad$ : nilai rata-rata

$\sum X$ : jumlah semua nilai siswa

$\mathrm{N}$ : banyak siswa

Berdasarkan Kurikulum 2013 di SMP

Negeri 1 Kota Bengkulu menyatakan ketuntasan belajar untuk (a) individu : jika siswa mendapat nilai $\geq 80$, (b) klasikal: jika $80 \%$ siswa mendapat nilai $\geq 80$. Presentase ketuntasan belajar klasikal dihitung dengan menggunakan rumus: 


$$
K B=\frac{n}{N} \times 100 \%
$$

(Purwanto, 2009:51)

Keterangan :

KB : ketuntasan belajar klasikal

$\mathrm{n} \quad$ : banyak seluruh siswa yang tuntas

$\mathrm{N}$ : banyak siswa

Siklus penilaian ini akan dihentikan jika kriteria keberhasilan tindakan telah tercapai. Adapun kriteria dan indikator keberhasilan tindakan peneliti adalah:

1. Hasil belajar siswa meningkat jika:

a. Minimal rata-rata klasikal siswa telah mencapai $\geq$ KKM mata pelajaran matematika yaitu 80

b. Minimal $80 \%$ siswa memperoleh nilai $\geq$ 80.

\section{HASIL DAN PEMBAHASAN}

Hasil belajar siswa pada ranah pengetahuan diperoleh berdasarkan nilai tes akhir siswa yaitu tes akhir setiap siklus. Tes belajar dilakukan untuk melihat keberhasilan guru dalam menerapkan model Problem Based Learning dalam pembelajaran. Berdasarkan analisis terhadap hasil belajar siswa maka diperoleh hasil sebagai berikut :

Tabel 5 Hasil Belajar Siswa Tiap Siklus

\begin{tabular}{|c|c|c|c|c|}
\hline Siklus & $\begin{array}{c}\text { Nilai } \\
\text { Rata- } \\
\text { rata }\end{array}$ & $\begin{array}{c}\text { Jumlah } \\
\text { siswa } \\
\text { yang } \\
\text { tuntas }\end{array}$ & $\begin{array}{c}\text { ketunta } \\
\text { san } \\
\text { belajar } \\
\text { klasikal } \\
(\boldsymbol{\%})\end{array}$ & $\begin{array}{c}\text { Indikator } \\
\text { keberhasilan } \\
\text { tindakan }\end{array}$ \\
\hline I & 74,27 & 24 & $72,73 \%$ & Belum tercapai \\
\hline II & 80,42 & 26 & $78,79 \%$ & Belum tercapai \\
\hline III & 82,96 & 28 & $84,85 \%$ & Tercapai \\
\hline
\end{tabular}

Berdasarkan tabel di atas, dapat dilihat bahwa terjadi peningkatan hasil belajar siswa secara berturut-turut dari siklus ke I sampai siklus ke III, yaitu nilai rata-rata siswa pada siklus ke I sebesar 74,27 meningkat disiklus II sebesar 80,42 dan meningkat ke siklus ke III sebesar 82,96. Pada siklus I ini nilai rata-rata siswa dan ketuntasan belajar secara klasikal masih kurang dari indikator keberhasilan yang diharapkan, sehingga dilanjutkan ke siklus II. Pada siklus II nilai rata-rata siswa 80,42 dan ketuntasan belajar secara klasikal $78,79 \%$.
Hasil siklus II ini masih belum memenuhi indikator keberhasilan sehingga dilanjutkan ke siklus III. Pada siklus III nilai rata-rata siswa mengalami peningkatan menjadi 82,96 dan ketuntasan belajar secara klasikal juga meningkat menjadi $84,85 \%$. Pada siklus III ini sudah memenuhi indikator keberhasilan baik untuk aktivitas siswa maupun hasil belajar siswa sehingga penelitian dihentikan. Peningkatan nilai rata-rata siswa dan ketuntasan belajar klasikal disebabkan pemahaman dan penguasaan siswa mengenai materi sudah mulai meningkat.

Rata-rata nilai akhir pada siklus III telah memenuhi indikator keberhasilan. Sedangkan peningkatan ketuntasan belajar secara klasikal dapat dilihat pada gambar grafik berikut:

\section{Gambar 1 Grafik Ketuntasan Hasil Belajar Klasikal}

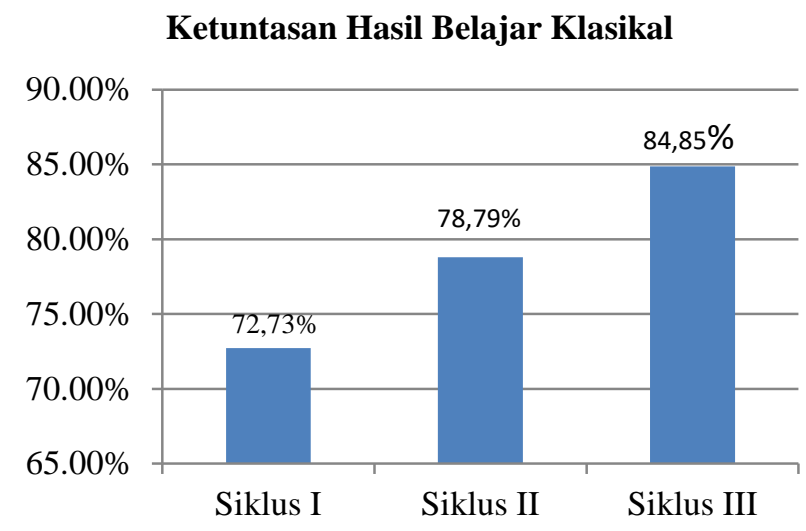

Persentase ketuntasan belajar pada grafik di atas mengalami peningkatan pada setiap siklus. Pada siklus I yaitu $72,73 \%$, hal ini berarti hanya 24 orang siswa yang memperoleh nilai $\geq 80$. Dan pada siklus II meningkat menjadi $78,79 \%$, yang berarti 26 orang siswa yang memperoleh nilai $\geq 80$, karena belum memenuhi indikator keberhasilan maka dilanjutkan pada siklus III. Pada siklus III ketuntasan belajar klasikal siswa meningkat hingga mencapai $84,85 \%$, yang berarti 28 orang siswa telah mencapai kriteria ketuntasan minimal yaitu $\geq 80$. Hal ini berarti pada siklus III ketuntasan belajar klasikal siswa sudah mencapai kriteria keberhasilan yaitu $\geq 80 \%$. 
Berdasarkan hasil tes siklus I, siklus II, dan siklus III setelah diterapkan model Problem Based Learning, hasil belajar siswa mengalami peningkatan dengan rata-rata hasil belajar siswa 82,96 pada siklus III dan ketuntasan belajar klasikal siswa mencapai 84,85\%. Berdasarkan Kurikulum 2013 di SMP Negeri 1 Kota Bengkulu untuk:

1. Individu: jika siswa mendapat nilai sesuai dengan Kriteria Ketuntasan Minimal (KKM) yaitu $\geq 80$ untuk tes pada setiap akhir siklusnya, sedangkan dalam penelitian ini rata-rata nilai akhir siswa untuk mencapai kriteria keberhasilan dalam penelitian yaitu rata-rata nilai akhir siswa $\geq 80$.

2. Klasikal: jika $80 \%$ dari jumlah siswa memperoleh nilai KKM $\geq 80$ untuk tes pada setiap akhir siklusnya sesuai dengan kriteria tingkat keberhasilan belajar siswa.

\section{Analisis Cara-Cara Peningkatan Hasil Belajar}

Pencapaian hasil belajar siswa dari siklus I sampai siklus III pada kelas VII 6 SMP N 1 Kota Bengkulu dengan penerapan model problem based learning yang dilakukan mengalami peningkatan ditinjau dari nilai ratarata siswa maupun ketuntasan belajar klasikalnya. Peningkatan hasil belajar siswa pada setiap siklus dapat dilihat pada gambar seperti berikut:

\section{Gambar 2 Grafik Hasil Belajar Siswa Setiap Siklus}

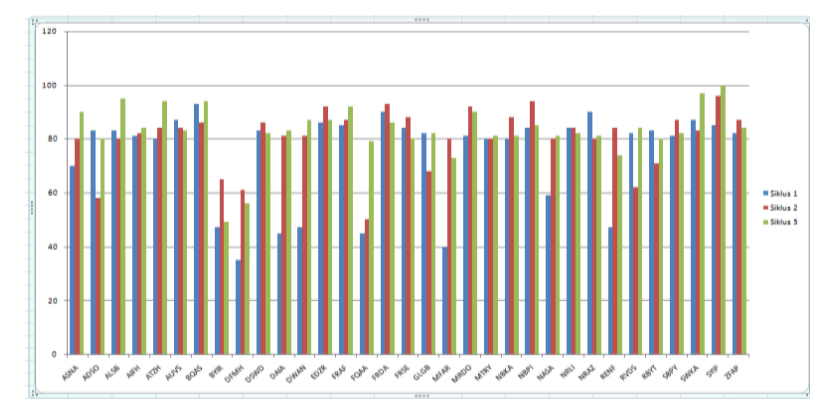

Gambar 2 dapat dilihat bahwa 10 orang siswa yang selalu meningkat tiap siklusnya, 9 orang siswa yang nilainya turun pada tes siklus II, dan 13 orang siswa yang nilainya turun pada tes siklus III. Selama tiga siklus, ada 3 orang siswa yang nilainya belum pernahh mencapai KKM, yaitu 80 dengan rincian: 1) BYIR dengan nilai siklus I yaitu 47 , siklus II nilainya 65, dan siklus III nilainya 49, dan 2) DFMH dengan nilai siklus I adalah 35 , nilai siklus II 61, dan siklus III nilainya 56, dan 3) FQAA dengan nilai siklus I adalah 45 , nilai siklus II adalah 50 dan siklus III nilainya 79 .

BYIR merupakan salah satu siswa yang tidak pernahh mencapai KKM pada setiap siklus. BYIR merupakan siswa yang pendiam, ini terlihat dia semi aktif dalam hal bekerja sama dengan kelompoknya. Siklus I nilainya hanya 47 dikarenakan BYIR hanya mengisi jawaban langsung tanpa menuliskan cara penyelesaian dan jawaban yang benar hanya 2 dari 5 yaitu nomor 2 dan 3. Soal nomor 2 diminta mencari keuntungan pedangang dari penjualan ayam, BYIR hanya membuat apa yang diketahui dan ditanya dari soal dan langsung jawaban tanpa jalan penyelesaian. BYIR mengira tes hasil belajar siklus I ini tidak berpengaruh terhadap nilainya sama guru matematika yang biasa mengajar dikelas, karena yang memberikan tes tersebut bukan gurunya maka BYIR tidak serius dalam mengerjakan tes hasil belajar siklus I ini.

Hal ini tidak terjadi terhadap BYIR saja, pada siklus I terdapat beberapa siswa yang tampak tidak serius dalam mengerjakan tes akhir dengan alasan yang sama seperti BYIR, diantaranya adalah siswa yang berinisial DFMH, DAIA, DWAN, FQAA, MFAR, dan RENF. Perbaikan tindakan yang dilakukan guru sebagai peneliti terhadap masalah tersebut adalah guru memotivasi siswa agar lebih mempersiapkan diri lagi ketika ujian akan berlangsung dan guru mengumumkan hasil tes akhir siklus I pada pertemuan pertama siklus II agar siswa lebih termotivasi untuk memperbaiki dan meningkatkan hasil belajarnya pada tes akhir siklus II. Guru juga

Sandi Lukito, Hanifah hanifah, Syafdi Maizora

Penerapan Model Problem Based Learning untuk Meningkatkan Hasil Belajar Matematika Siswa SMP 
menghimbau kepada siswa untuk serius dalam mengerjakan tes akhir belajar tiap siklus ini dan guru juga mengatakan kepada siswa bahwa nilai tes setiap siklus ini juga berpengaruh terhadap nilai rapornya nanti. Tindakan tersebut berhasil dilakukan untuk meningkatkan hasil tes siswa pada tes akhir siklus II, terlihat dari hasil belajarnya yang dapat dilihat pada gambar 1 .

DFMH juga merupakan salah satu siswa yang tidak pernahh mencapai KKM pada setiap siklus, menurut informasi dari siswa di kelas VII 6 DFMH merupakan siswa yang kurang dari segi akademik, bahkan berdasarkan laporan teman dekat DFMH untuk menyelesaikan perkalian sederhana saja DFMH kesulitan dalam menyelesaiakannya. Tindakan yang dilakukan guru tehadap DFMH dengan memberikan perhatian lebih dan menjelaskan materi secara pelan-pelan kepada DFMH juga tidak berhasil, DFMH hanya mengerti dan paham pada saat itu saja, untuk keesokannya DFMH kembali tidak dapat menyelesaikan soal yang diberikan.

FQAA merupakan salah satu dari tiga siswa yang tidak pernah mencapai KKM pada setiap siklus. FQAA merupakan siswa yang paling sering ribut dan usil terhadap temantemannya. Dalam diskusi kelompok FQAA sulit untuk diatur dan tenang. Tindakan yang dilakukan guru terhadap FQAA adalah memberi arahan dan perhatian lebih untuk mengikuti kegiatan pembelajaran dan diskusi kelompok dengan tenang dan serius. Tindakan ini berhasil dilakukan terlihat pada gambar 4.50 FQAA selalu mengalami peningkatan setiap siklusnya dan pada siklus III nilai FQAA hampir mencapai KKM yaitu 79 .

Gambar 2 juga terlihat bahwa pada tes hasil belajar siklus II ada 9 orang siswa yang nilainya menurun, diantaranya yaitu siswa yang berinisial ADSO, ALSB, AUVS, BQAS, GLGB, NRAZ, RVDS, RBYT, dan SWKA. Umumnya, siswa-siswa tersebut sudah benar dalam menjawab soal nomor 1 sampai 4 , hanya saja pada soal nomor 5 yaitu mencari nilai pajak UMKM dalam waktu satu bulan siswa tidak dapat menyelesaikan soal nomor 5 pada tes akhir siklus II karena kehabisan waktu.

Melihat kondisi tersebut, guru melakukan perbaikan tindakan untuk tes selanjutnya. Guru kembali memotivasi siswa pada pertemuan pertama siklus III untuk lebih berhati-hati dan teliti dalam menghitung angka dan menjawab soal, guru juga mengumumkan hasil tes belajar siswa siklus II tersebut, guru menekankan kepada siswa untuk selanjutnya lebih memperhatikan waktu pengerjaan.

Guru juga mengingatkan siswa pada setiap kali mengerjakan soal pada setiap tes akhir untuk membuat apa yang diketahui dan ditanyakan dari soal dan diakhir setiap jawaban diberikan kesimpulan, jika tidak dibuat maka tidak akan mendapatkan skor maksimal pada setiap soal, itulah yang membuat nilai menjadi rendah. Tindakan ini berhasil dilakukan 28 siswa sudah berhasil mendapatkan nilai diatas KKM pada tes akhir siklus III. Seluruh siswa sudah membuat apa yang diketahui dan ditanyakan dan juga sudah membuat kesimpulan akhir pada setiap jawaban soal yang ada.

\section{KESIMPULAN}

Peningkatan hasil belajar siswa dapat dilihat dari nilai rata-rata dan ketuntasan belajar siswa pada setiap siklus. Pada siklus I, nilai rata-rata hasil belajar siswa 74,27 dengan persentase ketuntasan belajar klasikal $72,73 \%$. Pada siklus II, nilai rata-rata hasil belajar siswa menjadi 80,42 dengan persentase ketuntasan belajar klasikal sebesar 78,79\%. Pada siklus III, nilai rata-rata hasil belajar siswa 82,96 dengan persentase ketuntasan belajar klasikal sebesar $84,85 \%$.

\section{SARAN}

Berdasarkan penelitian yang telah dilakukan maka peneliti memberikan beberapa saran, yaitu: (1) Guru harus mampu menjadi fasilisator yang baik, agar siswa fokus dalam belajar dan diskusi sehingga semua anggota kelompok bekerja pada setiap tahap. (2) Penerapan model Problem Based Learning 
hendaknya dapat menjadi salah satu upaya untuk mengembangkan sekolah kearah yang lebih baik terutama kualitas pembelajaran. (3) Penelitian mengenai penerapan model Problem Based Learning dalam pembelajaran matematika hendaknya lebih dikembangkan dengan penggunaan model-model pembelajaran jenis lain oleh peneliti-peneliti selanjutnya.

\section{DAFTAR PUSTAKA}

Arikunto, Suharsimi. 2012. Penelitian Tindakan Kelas. Jakarta: Bumi Aksara.

Dimyati, \& Mudjiono. (2010). Belajar dan Pembelajaran. Jakarta:Rineka Cipta.

Kementerian Pendidikan dan Kebudayaan. 2014. Matematika Kelas VIII. Jakarta: Kemendikbud.

Ngalimun. (2014). Strategi dan Model Pembelajaran. Yogyakarta:Aswaja Pressindo.
Rusman. (2011). Model-Model Pembelajaran Mengembangkan Profesionalisme Guru. Jakarta:Rajawali Pers

Sitiatava Rizema. 2012. Desain Belajar Mengajar Kreaktif Berbasis Sains. Jogjakarta : Diva Press.

Sardiman. (2012). Interaksi \& Motivasi Belajar Mengajar. Jakarta: Raja Grafindo Persada. Sudjana, Nana. (2006). Penilaian Hasil Proses Belajar Mengajar. Bandung: Remaja Rosdakarya.

Susanto, Ahmad. (2014). Teori Belajar dan \& Pembelajaran di Sekolah Dasar. Jakarta:Kencana.

Ula, S.Shoimatul. 2013. Revolusi Belajar: Optimalisasi Kecerdasan melalui Pembelajara Berbasis Kecerdasan Majemuk. Jakarta: Ar-Ruzz Media. 